\begin{tabular}{|c|c|}
\hline Proceeding of the $9^{\text {th }}$ ICEE Conference 3-5 April 2018 & NBC \\
Military Technical College \\
Kobry El-Kobbah, \\
Cairo, Egypt
\end{tabular}

NBC-1

\title{
Comparison between the Effect of using Similar Wedges and Opposed Wedges in Brain Tumor Cases
}

\author{
Shaimaa G.Ghazy ${ }^{1}$, Amr Abdelaziz A ${ }^{2}$, Heba S Ramadan ${ }^{3}$, Sabbah I. Hammoury ${ }^{4}$, \\ Yasser I. Khedr ${ }^{5}$, Metwally A. Kotb ${ }^{6}$
}

\begin{abstract}
Introduction: Radiotherapy still the most facilitated modality for treatment malignant brain tumors with or without chemotherapy and after surgery or when surgery is impossible. Purpose: Comparison between the effects of three planning techniques with similar, opposed and non-wedges in brain tumor cases. Methods: Twenty patients with brain tumors (Glioblastoma Multiform) of both sexes were enrolled in the study. A LINAC with $6 \mathrm{MV}$ photon beam was used to deliver the prescribed dose. The whole brain technique was applied to each patient and the planning was constructed with nonwedges, similar wedges and opposed wedges within $95 \%$ to $107 \%$ of the prescribed dose as recommended by the RTOG. The considered organs at risk were; Right and Left (eyes, lenses, and optic nerves), optic chiasma and the brain- stem. Results: The results showed significant difference (at the level $\mathrm{P}<0.05$ ), between the three planning based on the conformity, homogeneity indexes, global max, and the doses received by the OARs. The results were discussed.
\end{abstract}

\section{Keywords:}

Radiotherapy; brain tumor; Linac; Wedges; Conformity Index; Homogeneity Index

1- Radiation Therapy Depart. , Armed Forces Hospital, Alexandria.

2- Oncology Depart. , Faculty of Medicine, Alexandria University.

3, 6- Medical Biophysics Depart. , Medical Research Institute, Alexandria University.

4- Radiation Therapy Depart. , Ayaddi Al Mustakbal Hospital, Alexandria.

5- Physics Depart. , Faculty of Science, Damanhour University 
Military Technical College

Kobry El-Kobbah, Cairo, Egypt

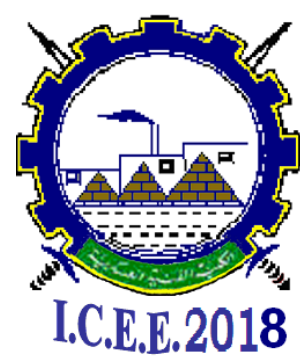

$9^{\text {th }}$ International Conference

on

Chemical \& Environmental

Engineering

3-5 April 2018

\section{1-Introduction}

There are more than 200 types of human cancer, each with different causes, symptoms and treatments. In general, cancer is predominantly an environmental disease with 90$95 \%$ of cases being attributed to lifestyle factors, and 5-10\% due to genetics. [1] While cancer can affect people of all ages the overall risk of developing cancer generally increases with age, at least up to age 80-85 yr. In 2007, cancer caused about $13 \%$ of all human deaths worldwide ( 7.9 million). These rates are rising as more people live to an old age and as lifestyle changes occur in the developing world.[2] According to the United Nations, World Population Prospects, (2013), cancer incidence rates projected increase ,2012-2030, worldwide. The age-standardized rate was at least 300 per 100,000 for nine countries (Denmark, France, Australia, Belgium, Norway, United States of America, Ireland, Republic of Korea and The Netherlands). Denmark is known as the cancer capital of the world as this deadly disease affects the highest number of people. The reported numbers of cases are high in this country as doctors are able to diagnose it on the forefront as compared to other countries. The high rates of alcohol consumption and smoking increase the risk of cancer in this country.

Other significant factors that facilitate the development of cancer include increase obesity rates and sedentary lifestyles.

A malignant brain tumor is a fast-growing cancer that spreads to other areas of the brain and spine. Cancer of the brain can be a primary brain tumor that originates in the brain or a metastatic (secondary) brain tumor that originates from cancer cells that have migrated from other parts of the body. Most malignant tumors are secondary cancers, which mean they started in another part of the body and spread to the brain. Primary brain tumors are those that started in the brain. Brain tumors do not discriminate. Primary brain tumors those that begin in the brain and tend to stay in the brain - occur in people of all ages, but they are statistically more frequent in children and older adults. Metastatic brain tumors those that begin as a cancer elsewhere in the body and spread to the brain - are more common in adults than children.

A primary malignant brain tumor needs to be treated as soon as possible, because it can spread and damage other parts of the brain and spinal cord.

Surgery, radiation therapy and chemotherapy are common methods of treatment of brain tumors. Usually, more than one treatment is often used to treat the tumor, and this depends on the size, type, tumor location, additional medical problems and the age of the patient. Clinical trials offer new treatments for willing patients.

Radiotherapy, on the other hand, uses controlled doses of high energy radiation beams to destroy brain tumor cells whilst causing as little damage as possible to surrounding cells. With the inventions of X-rays, medical linear accelerators (Linacs) with energies up to $35 \mathrm{MV}, \mathrm{X}$-rays started to be used in medical radiation therapy [3]. The development of computed tomography (CT) in 1970, created a shift from 2 - D to 3 - D radiation delivery. 
Military Technical College

Kobry El-Kobbah, Cairo, Egypt

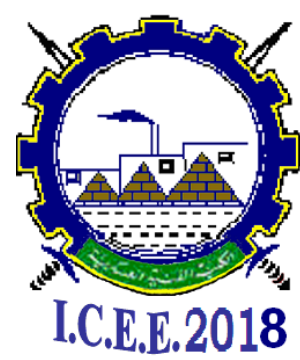

$9^{\text {th }}$ International Conference

on

Chemical \& Environmental

Engineering

3-5 April 2018

Computed tomography (CT) or magnetic resonance imaging (MRI) scans are recently available to delineate tumors and adjacent normal structures in three dimensions [4] This enables the profile of each radiation beam to be shaped to fit the profile of the target from a beam's eye view (BEV) using a multileaf collimator (MLC) and a variable number of beams. When the treatment volume conforms to the shape of the tumor, the relative toxicity of radiation to the surrounding normal tissues is reduced, allowing a higher dose of radiation to be delivered to the tumor than conventional techniques would allow. [5] According to the ICRU-report 50, the critical target volume (CTV) has to obtain $100 \%$ of the radiation dose with a dose distribution of highest homogeneity $(100 \%$ $-5 \%+7 \%$ ).

Quantification of three dimensional dose distribution is represented in the form of dosevolume histograms that can be used to define the maximum, minimum, mean, and modal dose values delivered to each volume of interest, as well as the dose delivered per unit or percentage volume of these structures. The dose distribution modeling is easy to interpret for the tumor volume, because it defines the isodose that covers a given percentage of the tumor volume. This modeling also indicates the doses delivered to the critical organs delineated (particularly the maximum doses and doses delivered per unit or percentage of volume of critical organs), and allows comparison of these doses to theoretical doses considered to be the maximum tolerated doses. [6] In modern radiation therapy, 3D dose distributions are typically created in a computerized treatment planning system (TPS) based on a 3D reconstruction of a CT scan. The aim of the present work is to study the comparison between the effect of using similar wedges, opposed wedges, and using no wedges in glioblastoma brain tumor cases.

\section{2- Subjects and Methods}

Twenty patients of both sexes with histopathologically confirmed brain tumors from a hospital in Alexandria city (in Oncology center of Armed Forces Hospital) with an age range of $(30-60 \mathrm{yrs})$ were recruited in this study from 1st January 2015 to 30 th March 2017. Alexandria University; approved the study protocol and all experimental procedures are in accordance with the Helsinki Declaration of 1975, as revised in 1983. All participants were instructed about the planning, procedures and benefits and provided a signed informed written consent prior to their inclusion in the study protocol treatment procedures.

\section{2-1 Planning}

\section{2-1-1 Importing images and contouring:}

The images received from the CT scanner are transferred to the treatment planning system (TPS). The acquisition, contour of the planning target volumes (PTV) and the critical volumes of organs at risk (OARs) were performed according to the Radiation Therapy Oncology Group (RTOG). The organs at risk, in this work, included: bilateral 
Military Technical College

Kobry El-Kobbah, Cairo, Egypt

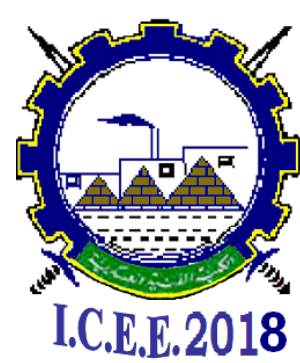

$9^{\text {th }}$ International Conference

on

Chemical \& Environmental

Engineering

3-5 April 2018

optic nerves, eye balls, lenses, brain-stem and optic chiasma, which were delineated by radiation oncologist on the $\mathrm{CT}$ slices using contouring workstation (version 5.1 Prowess Inc, Concord , CA, USA) [7] treatment planning system (TPS).

\section{2-1-2 Treatment plans designing:}

All the treatment plans were created by the medical physicist in steps:

1- Determination of field geometry and isocenter:

Lateral beams (anterior border was $2 \mathrm{~cm}$ posterior to lens, inferior border was the bottom of C2 vertebra) with the isocenter placed in the patients' midline. For each patient, three different treatment plans were created for whole brain. The prescribed dose of PTV was $30 \mathrm{~Gy}$ in 10 fractions and the dose rate of the irradiation field was $300 \mathrm{MU} / \mathrm{min}$.

2- The resulting calculations of the dose distribution for three plans (with no wedges, similar wedges and opposed wedges), were evaluated. According to the PTV the following criteria were estimated: i) The doses (D2, D5, D50, D95 ,D98, and D100) of the prescribed dose received by the target volume, and the volumes V2, V5, V50, V95, V107 covered by $2 \%, 5 \%, 50 \%, 95 \%$ and $107 \%$ of the PTV, the minimum, maximum and mean doses received by the PTV, in addition to the homogeneity index (HI)[8], the uniformity index (UI)[9], and the conformity index (CI) [10] using the DVH.ii) According to organs at risk (OARs): The minimum, maximum and mean doses of (Rt ,Lt) lenses, eye balls and optic nerves), optic chiasma and brain-stem), D2, D5, D95, D98 and $\mathrm{D} 100, \mathrm{~V} 2 \%, \mathrm{~V} 5 \%, \mathrm{~V} 50 \%, \mathrm{~V} 95$ and V107\% of (Rt ,Lt) eye balls and optic nerves, optic chiasma and brain-stem.

3- Exporting the optimal plans to the (Lantis) software and then transferring to (Prim View) software by DICOM (The Digital Imaging and Communications of Medicine) network.

\section{2-1-3 Treatment planning machine:}

The patient was placed on the Medical Linear accelerator table (Primus High Klystron class) [11], on the supine position, and adjusting this position using patient-positioning System LAP "Astor red".

\section{3- Results and Discussion}

Radiation therapy in its main objectives aims to deliver maximum dose to the target volume homogeneously, while avoiding dose to the normal surrounding structures.

[12] Progress made in last few decades in medical imaging and dosimetric software has allowed achieving this objective by visualization of the spatial dose distribution within the target volumes. As a result of these developments, various treatment plans can now be easily and rapidly obtained for the same patient, in addition to the reliability of using numerous parameters that enables the best choice and make good chances of preferring between the suggested plans.

The dose distribution in these plans can be visualized in the form of dose-volume histograms (DVHs) and isodose lines, to define parameters such as maximum dose 
Military Technical College

Kobry El-Kobbah, Cairo, Egypt

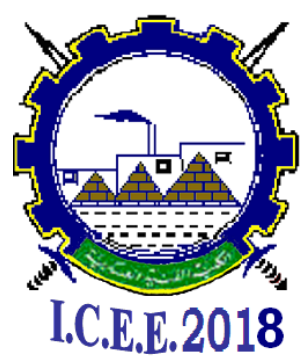

$9^{\text {th }}$ International Conference

on

Chemical \& Environmental

Engineering

3-5 April 2018

(Dmax), minimum dose (Dmin), mean dose (Dmean) and modal dose delivered to each volume of interest.Accordingly, large volume of data obtained by these histograms, lines and curves can be used to compare between different treating plans performed for each treatment case. [13]

However, the treating radiation oncologist determined acceptable treatment radiation doses for both the planning target volume and the organs at risk associated with each site of the tumor and its surrounding organs that are critical or that have to receive as minimum as possible of the pre-described dose.

In most situations it is important to make a choice in favor of a plan is required to provide maximum tumor coverage homogeneously and protects healthy tissues at the same time.

For this purpose, another or additional parameters are introduced for this purpose. Of these addition parameters, the homogeneity index (HI) [14] and the conformity index (CI) are two such tools for treatment plan analysis have been introduced in conformal radiotherapy.

In the present work, the study was performed on 20 patients of both sexes for treatment of glioblastoma brain tumors. For each patient, three plans were created for the purpose of comparison. The first plan was performed without the use of wedges. The other two plans employed the use of similar and opposed wedges, respectively.

The wedge angles were designed as $15^{\circ}$ and using $6 \mathrm{MV}$ photons, the gantry angles were designed as $\leq 90^{\circ}$ and $\geq 270^{\circ}$, the collimator angles were designed as $\leq 50^{\circ}$ and $\geq 310^{\circ}$ that could be shown in digital reconstructed radiograph (DRR). A CT (Computed Tomography) scans based radiographic volume data set was used for the definition of target volumes, organs at risk, and other structures of interest.

The target volumes like Gross Tumor Volume (GTV), Clinical Target Volume (CTV) and PTV were defined as per their definitions in International Commission on Radiation Units and Measurements (ICRU) Report 50. [15]

The planning was done with the following aims: minimum dose greater than or equal to $95 \%$ and the maximum dose less than or equal to $107 \%$ of the prescribed dose are received by the planning target volume. The normalization of each plan followed the recommendation of ICRU report 50. The ICRU point was used for normalization and was set at $100 \%$.

\subsection{Planning Target Volume (PTV):}

When the CT target volume data was analyzed, volume of the PTV varied from 1056 $1567.7 \mathrm{~cm} 3$ with mean value $1322.2 \pm 150.4 \mathrm{~cm} 3$, respectively.

\subsection{Comparing Received Doses:}

The dose distribution in the three plans could be visualized in the form of dose-volume histograms (DVHs), to define parameters such as maximum dose (D max), minimum dose (D min), mean dose (D mean) and modal dose delivered to each volume of interest, 
Military Technical College

Kobry El-Kobbah, Cairo, Egypt

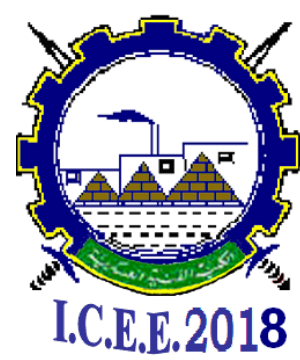

$9^{\text {th }}$ International Conference

on

Chemical \& Environmental

Engineering

3-5 April 2018

and/or the organs at risk. Large volume of data was obtained by these dose-volume histograms could be used to compare between the different three performed plans. In most situations it was important to make a choice in favor of a plan to provide maximum tumor coverage homogeneously and protects healthy tissues at the same time. For this purpose, another additional parameters were introduced, e.g., the homogeneity index (HI) [16], the conformity index (CI) [17], and the global maximum.

As revealed by the obtained data, and referring to Table (1),There is a highly significant difference between the mean of any described dose level of the three plans, at the level of $\mathrm{p}(<0.05)$, except for D100, where the difference is not significant at this level of significance. However, the situation of using opposed wedges was closest to the prescribed dose for the levels D2\% and D5\% and D50\%, while no wedges situation was closest to the prescribed dose for the levels D98\% and D100\%, respectively.

On considering the maximum, minimum, and mean dose received by the PTV, as shown in Table (2), the closest mean value to the prescribed dose is in using opposed wedges situation, as judged by both Fig. (1) and Fig. (2) from the dose volume histogram of the three planning procedures described.

\subsection{Comparing the Volumes Coverage:}

In case of the volume of the PTV coverage by $95 \%$ (V95) of the dose both the nonwedges and the opposed wedges produce maximum volume covered by $95 \%$ of the dose, Fig. (3). While, in considering the volume of the PTV covered by $107 \%$ of dose the similar and opposed wedges are better than the situation of no wedges, because the PTV in this case receive zero dose.

\subsection{Comparing the planning quality in case of PTV Homogeneity Index:}

Various definitions and formulae have been described in literature by various authors and organizations, [18-20] to consider its availability as a tool of comparison between the different planning treatment options. Moreover, less emphasis has been given to this parameter as compared to other treatment planning parameters. In addition, there is a paucity of data in literature regarding the factors that influence HI and the extent of such influence. A search for these factors can enhance our understanding regarding HI, which will allow us to better analyze the spatial dose distribution in the treatment plans.

In all definitions, HI basically indicates the ratio between the maximum and minimum dose in the target volume and the lower value indicates a more homogenous dose distribution within this volume. The $\mathrm{HI}$ in the present work was calculated using the following formula: HI= [(D2-D98)/D50] [21], Where D2 is the minimum dose in 2\% of the Planning Target Volume (PTV), indicating the "maximum dose", D98 = minimum dose to the $98 \%$ of the target volume, indicating the "minimum dose" and D50 = minimum dose to the $50 \%$ of the target volume. As described by the Radiation Therapy Oncology Group RTOG, the value approaching zero is the better indication of the dose distribution in the target volume. Considering this concept, and referring to the data 
Military Technical College

Kobry El-Kobbah, Cairo, Egypt

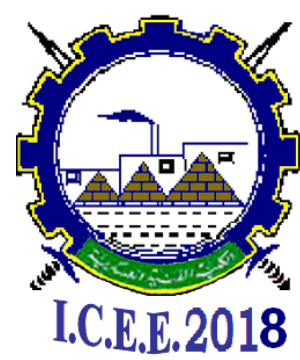

$9^{\text {th }}$ International Conference

on

Chemical \& Environmental

Engineering

3-5 April 2018

obtained in this work Table (3). for the HI within the PTV, we can conclude that the better situation between the three planning treatments suggested in this work is either the non wedges and opposed wedges treatment plan where the mean $\mathrm{HI}$ value $\pm \mathrm{SD}$, corresponds to $0.10 \pm 0.14$ and $0.11 \pm 0.11$ for this two plans, respectively.

This is also true with respect to the uniformity index and/or the conformity index where the estimated values for these two parameters are closest to unity in case of the non wedges and opposed wedges treatment plans where the mean UI value and the conformity value $\pm \mathrm{SD}$, correspond to $1.087 \pm 0.010$ and $0.99 \pm 0.001$ for the non-wedge situation and $1.09 \pm 0.012$ and $0.913 \pm 0.058$ for the opposed wedges situation, respectively.

\subsection{Global Max of the PTV:}

In considering the global maximum as another parameter of comparison between the radiotherapy planning constructed in this work, it is clear from the data obtained in this work and referring to Table (4), and Fig. (4), that we have to exclude the non-wedge situation and accept either the similar or the opposed wedges planning since they are close to the accepted $107 \%$, as a limit of acceptance.

However, referring to the obtained screens of the considered brain tumor cases in this work to differentiate between opposed and similar wedges of the same patient, as seen in Fig. (5) and (6), the global max in case of using similar wedges $108.15 \%$ and $109.9 \%$ for the opposed wedges planning, but the area covered by more than $105 \%$ of the prescribed dose is much smaller in the opposed wedges plan than the similar wedge plan, so, in our opinion the opposed wedge plan is better than that in the similar wedge plan.

\subsection{Organs At Risk}

The organs at risk that considered in the present study were the right and left lenses, the right and left eyes, the right and left optic nerves, the brain chiasma and the brain- stem. The size of each of these organs was estimated from the CT scan, and the same parameters applied for the PTV were also considered.

Tables (5-7), describe the mean of minimum, maximum, and mean doses of each organ at risk that was taken into consideration as required by the RTOG in case of brain tumors treated with radiotherapy.

According to the data presented in Table (5), no significant difference exists between the three planning techniques except in optic chiasma and the brain-stem, which are coinciding with the mean doses received, as illustrated in Table (7).

However, in considering the mean maximum doses received there is also significant difference in both the mean doses received by the left and the right optic nerves. Since these organs are of utmost importance in case of treating brain tumors with radiotherapy, and the oncologist side by side with the radiologist bear in mind the preferable planning methodology that delivers as minimum as possible radiation doses to these critical organs, so, the opposed wedges situation followed in this work with the proposed wedges angles mentioned in the present study. 
Military Technical College

Kobry El-Kobbah, Cairo, Egypt

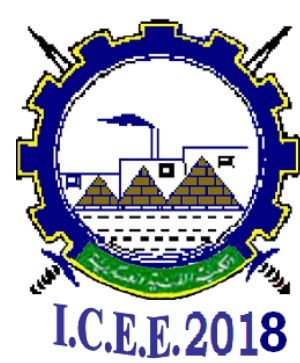

$9^{\text {th }}$ International Conference

on

Chemical \& Environmental

Engineering

3-5 April 2018

\section{4- References:}

[1] P Anand, AB Kunnumakkara, C Sundaram, K B Harikumar, S T Tharakan, O S Lai and et al, "Cancer is a preventable disease that requires major lifestyle changes", Pharm Res (2008) 2097-2116.

[2] JF Fraumeni, D Schottenfeld and JM Marshall, Cancer epidemiology and prevention, Oxford University Press, USA, 2006, p 977.

[3] D Bufalouk and H Gogas, The treatment of brain metastases in melanoma patients, Cancer Treat Rev (2004) 515-520.

[4] MK Bucci, A Bevan and M Roach, "Advances in radiation therapy: conventional to 3D, to IMRT, to 4D, and beyond", CA Cancer J Clin (2005) 117-134. KA Camphausen and RC Lawrence, "Principles of Radiation Therapy" In: Cancer Management: A Multidisciplinary Approach, Pazdur R, Wagman LD, Camphausen KA, Hoskins WJ (eds). Cancer Management, USA, 2008, pp 1070-2005.

[5] C-W Cheng and IJ Das, Treatment plan evaluation using dose-volume histogram $(\mathrm{DVH})$ and spatial dose - volume histogram (zDVH), Int J Raiat Oncol Biol Phys (1999) 1143-1150.

[6] BJ Salter, V Sarka, B Wang, H Shukla, M Szegedi and P Rassiah-Szegedi, Rotational IMRT delivery using a digital linear accelerator in very high dose rate 'burst mode', Phy Med Biol (2011) 1931-1946.

[7] T Kataria, K Sharma, V Subramani, KP Karrthick and SS Bisht, Homogeneity Index: An objective tool for assessment of conformal radiation treatments, J Med Phys (2012) 207-213.

[8] R Prabhakar, Dose volume uniformity index: a simple tool for treatment plan evaluation in brachytherapy, J Contemp Brachytherapy (2010) 71-75.

[9] NJ Lomax and SG Scheib, Quantifting the degree of conformity in radiosurgery treatment planning, Nt J Radiat Oncol Biol Phys(2003) 1409-1419.

[10]VA Semerenko, B Reitz, E Day, XS Qi, M Miften and XA Li, Evaluation of a commercial biologically based IMRT treatment planning system, Med Phys (2008) 5851-5860.

[12] SH Son, BO Choi and G Kim, Radiation Therapy in Hematologic Malignancies: An Illustrated Practical Guide, Curr Opin Ophthalmol (2008) 414-421.

[13] MM Austin-Seymour, GT Chen, JR Castro, WM Saunders, S Pitluck, KH Woodruff and et al, Dose volume histogram analysis of liver radiation tolerance, Int J Radiat Oncol Biol Phys (1986) 31-35.

[14] P Pathak , S Vashisht A quantitative analysis of intensity- modulated radiation therapy plans and comparison of homogeneity indices for the treatment of gynecological cancers, J Med Phys (2013) 67-73.

[15]ICRU Report 50: Prescribing, Recording and Reporting Photon Beam Therapy, Bethesda MD: International Commission on Radiation Units and Measurements, 1993, p 72. 
Military Technical College

Kobry El-Kobbah,

Cairo, Egypt

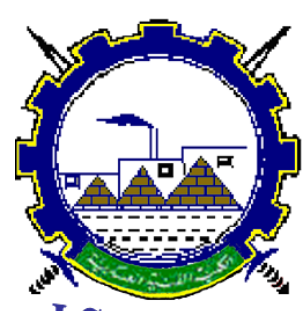

I.C.E.E.2018 $9^{\text {th }}$ International Conference

on

Chemical \& Environmental

Engineering

3-5 April 2018

[16]T Kataria, K Sharma, V Subramani, KP Karrthick and SS Bisht, Homogeneity Index: An objective tool for assessment of conformal radiation treatments, J Med Phys (2012) 207-213.

[17]L Feuvret, G Noel, JJ Mazeron and P Bey, Conformity index - a review, Int J Radiat Oncol Biol Phys(2006) 333-342.

[18]E Shaw, R Kline, M Gillin, L Souhami, A Hirschfeld, R Dinapoli and et al, Radiation Therapy Oncology Group: Radiosurgery quality assurance guidelines. Int J Radiat Oncol Biol Phys(1993) 1231-1239.

[19] Y Gong, J Wang, S Bai, X Jiang and F Xu, Conventionally-fractionated imageguided intensity modulated radiotherapy (IG-IMRT): A safe and effective treatment for cancer spinal metastasis, Radiat Oncol (2008) doi: 10.1186/1748-717X-3-11.

[20]Q Wu, R Mohan, M Morris, A Lavue and R Schmidt-Ullrich, Simultaneous integrated boost intensity-modulated radiotherapy for locally advanced head-andneck squamous cell carcinomas: Dosimetric results, Int J Radiat Oncol Biol Phys (2003) 573-585

[21]P Pathak , S Vashisht . A quantitative analysis of intensity-modulated radiation therapy plans and comparison of homogeneity indices for the treatment of gynecological cancers. J Med Phys (2013); 38(2): 67-73. 
Military Technical College

Kobry El-Kobbah,

Cairo, Egypt

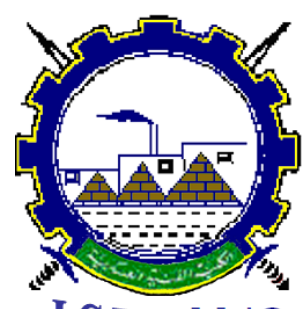

I.C.E.E.2018 $9^{\text {th }}$ International Conference

on

Chemical \& Environmental

Engineering

3-5 April 2018

Table 1: Different doses (in cGy) delivered to different fractions of the (PTV)

\begin{tabular}{|c|c|c|c|c|}
\hline Dose & $\begin{array}{c}\text { Non } \\
\text { wedges }\end{array}$ & Similar Wedges & Opposed Wedges & $\overline{\mathrm{P}(<0.05)}$ \\
\hline & \multicolumn{3}{|c|}{ Mean \pm SD } & \\
\hline D2\% & $\begin{array}{c}3315.24 \\
\pm 43.14\end{array}$ & $\begin{array}{l}3137.7 \\
\pm 13.68\end{array}$ & $\begin{array}{l}3125.9 \\
\pm 18.64\end{array}$ & $0.000^{*}$ \\
\hline D5 \% & $\begin{array}{l}3265.7 \\
\pm 38.7\end{array}$ & $\begin{array}{l}3102.1 \\
\pm 18.12\end{array}$ & $\begin{array}{l}3091.7 \\
\pm 19.76\end{array}$ & $0.000^{*}$ \\
\hline$\overline{\mathrm{D} 50 \%}$ & $\begin{array}{l}3101.7 \\
\pm 15.87\end{array}$ & $\begin{array}{l}2896.5 \\
\pm 32.54\end{array}$ & $\begin{array}{c}2932.05 \\
\pm 20.23\end{array}$ & $0.000 *$ \\
\hline D95\% & $\begin{array}{l}3000.7 \\
\pm 12.07\end{array}$ & $\begin{array}{l}2688.8 \\
\pm 37.49\end{array}$ & $\begin{array}{l}2840.5 \\
\pm 21.25\end{array}$ & $0.000^{*}$ \\
\hline D98\% & $\begin{array}{c}2985.65 \\
\pm 10.18\end{array}$ & $\begin{array}{c}2654.15 \\
\pm 40.16\end{array}$ & $\begin{array}{c}2792.05 \\
\pm 27.39\end{array}$ & $0.000^{*}$ \\
\hline D100\% & $\begin{array}{r}1393.65 \\
\pm 806.75\end{array}$ & $\begin{array}{r}1411.28 \\
\pm 806.69\end{array}$ & $\begin{array}{r}1300.36 \\
\pm 745.92\end{array}$ & 0.609 \\
\hline
\end{tabular}

*Doses expressed as Mean \pm SD

Table 2: Maximum, Minimum, and Mean doses (in cGy) received by the (PTV)

\begin{tabular}{|c|c|c|c|c|}
\hline Dose & Non Wedges & Similar Wedges & $\begin{array}{c}\text { Opposed } \\
\text { Wedges }\end{array}$ & $\mathrm{P}(<0.05)$ \\
\hline Maximum & 3365.58 & 3202.38 & 3201.67 & $0.000^{*}$ \\
dose & \pm 38.77 & \pm 9.05 & \pm 15.52 & \\
\hline Minimum & 1394.08 & 1361.84 & 1649.4 & 0.699 \\
dose & \pm 807.12 & \pm 752.23 & \pm 746.1 & \\
\hline Mean & 3108.86 & 2892.29 & 2943.2 & $0.000^{*}$ \\
dose & \pm 19.67 & \pm 26.46 & \pm 20.19 & \\
\hline V95 & 98.56 & 63.6 & 91.24 & $0.000^{*}$ \\
& \pm 1.47 & \pm 8.91 & \pm 5.88 & \\
\hline V107 & 13.06 & 0 & 0 & $0.000^{*}$ \\
& \pm 5.53 & & & \\
\hline
\end{tabular}

*Doses expressed as Mean \pm SD. 


\begin{tabular}{|c|c|}
\hline Proceeding of the $9^{\text {th }}$ ICEE Conference 3-5 April 2018 & NBC \\
$\begin{array}{c}\text { Military Technical College } \\
\text { Kobry El-Kobbah, } \\
\text { Cairo, Egypt }\end{array}$ & $\begin{array}{c}9^{\text {th }} \text { International Conference } \\
\text { on }\end{array}$ \\
& Chemical \& Environmental \\
& Engineering \\
\hline
\end{tabular}

Table3: Estimated values of (HI, UI, CI, and global maximum) \pm SD for PTV

\begin{tabular}{|c|c|c|c|c|c|}
\hline \multirow{3}{*}{ Indices } & \multicolumn{3}{|c|}{ Situation } & \multirow{2}{*}{$(<0.05)$} \\
\cline { 2 - 5 } & & Non Wedges & Similar Wedges & Opposed Wedges & \\
\hline \multirow{3}{*}{ HI } & Median & 0.103 & 0.165 & 0.114 & \multirow{2}{*}{$0.000^{*}$} \\
\cline { 2 - 5 } & Mean & 0.102 & 0.165 & 0.113 & \\
& \pm SD & \pm 0.14 & \pm 0.012 & \pm 0.11 & \\
\hline \multirow{3}{*}{ UI } & Median & 1.089 & 1.15 & 1.09 & \multirow{3}{*}{$0.000^{*}$} \\
\cline { 2 - 6 } & Mean & 1.087 & 1.15 & 1.09 & \\
\hline \multirow{3}{*}{ CI } & \pm SD & \pm 0.01 & \pm 0.012 & \pm 0.0124 & \\
& Median & 0.99 & 0.636 & 0.937 & \\
\cline { 2 - 6 } & Mean & 0.99 & 0.636 & 0.913 & \\
\hline \hline
\end{tabular}

Table 4: Global Max of the PTV

\begin{tabular}{|c|c|c|c|c|}
\hline Global Max & $\begin{array}{c}\text { Non wedges } \\
(n=20)\end{array}$ & $\begin{array}{c}\text { Similar wedges } \\
(n=20)\end{array}$ & $\begin{array}{l}\text { Opposed wedges } \\
(\mathrm{n}=20)\end{array}$ & \multirow{7}{*}{$0.000 *$} \\
\hline Minimum & 113.4 & 106.96 & 108 & \\
\hline Maximum & 119.45 & 109.34 & 111.9 & \\
\hline Median & 116.25 & 107.995 & 110.16 & \\
\hline Mean & 116.11 & 108.153 & 109.9 & \\
\hline \pm S.D. & 1.498 & 6.13 & 1.14 & \\
\hline $\begin{array}{c}\text { Significance } \\
\text { between groups }\end{array}$ & $\mathrm{P} 1=0.000^{*}$ & $\mathrm{P} 2=0.000^{*}$ & $\mathrm{P} 3=0.000^{*}$ & \\
\hline
\end{tabular}


Military Technical College

Kobry El-Kobbah,

Cairo, Egypt

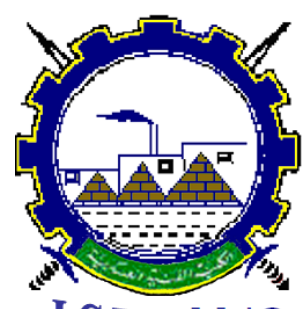

I.C.E.E.2018 $9^{\text {th }}$ International Conference

on

Chemical \& Environmental

Engineering

3-5 April 2018

Table 5: Comparison between the mean of the minimum doses received by the OARs

\begin{tabular}{|c|c|c|c|c|c|c|c|c|c|}
\hline Situation & & $\begin{array}{l}\text { Rt } \\
\text { Lens }\end{array}$ & $\begin{array}{l}\text { Rt } \\
\text { Eye }\end{array}$ & $\begin{array}{l}\text { Left } \\
\text { Lens }\end{array}$ & $\begin{array}{l}\text { Left } \\
\text { Eye }\end{array}$ & $\begin{array}{c}\text { Left } \\
\text { Optic } \\
\text { Nerve }\end{array}$ & $\begin{array}{c}\text { Rt } \\
\text { Optic } \\
\text { Nerve }\end{array}$ & $\begin{array}{c}\text { Optic } \\
\text { Chiasma }\end{array}$ & $\begin{array}{l}\text { Brain- } \\
\text { Stem }\end{array}$ \\
\hline $\begin{array}{c}\text { Non } \\
\text { Wedges }\end{array}$ & \multirow{3}{*}{$\begin{array}{l}\text { Min } \\
\pm \text { SD }\end{array}$} & $\begin{array}{c}\mathbf{2 4 9 . 6 9} \\
58.07\end{array}$ & $\begin{array}{l}\mathbf{2 0 9 . 5} \\
39.18\end{array}$ & $\begin{array}{c}\mathbf{2 4 1 . 3 1} \\
41.33\end{array}$ & $\begin{array}{c}\mathbf{1 9 8 . 5 1} \\
35.24\end{array}$ & $\begin{array}{l}\mathbf{8 6 1 . 3 3} \\
750.56\end{array}$ & $\begin{array}{l}\mathbf{9 0 8 . 8 1} \\
576.15\end{array}$ & $\begin{array}{c}\mathbf{3 0 4 2 . 0} \\
38.47\end{array}$ & $\begin{array}{c}3010.0 \\
32.21\end{array}$ \\
\hline $\begin{array}{l}\text { Similar } \\
\text { wedges }\end{array}$ & & $\begin{array}{c}\mathbf{2 6 1 . 1 9} \\
51.24\end{array}$ & $\begin{array}{l}\mathbf{2 2 2 . 6} \\
35.07\end{array}$ & $\begin{array}{c}\mathbf{2 5 4 . 8 9} \\
34.72\end{array}$ & $\begin{array}{c}\mathbf{2 1 1 . 7 0} \\
31.81\end{array}$ & $\begin{array}{l}863.26 \\
743.85\end{array}$ & $\begin{array}{l}\mathbf{9 1 4 . 5 6} \\
560.36\end{array}$ & $\begin{array}{c}\mathbf{2 9 5 3 . 7} \\
30.66\end{array}$ & $\begin{array}{c}\mathbf{2 8 4 7 . 6} \\
27.71\end{array}$ \\
\hline $\begin{array}{l}\text { Opposed } \\
\text { wedges }\end{array}$ & & $\begin{array}{c}\mathbf{2 3 7 . 9 5} \\
46.94\end{array}$ & $\begin{array}{l}\mathbf{2 0 3 . 4} \\
30.48\end{array}$ & $\begin{array}{c}\mathbf{2 3 3 . 0 6} \\
33.33\end{array}$ & $\begin{array}{c}\mathbf{1 9 4 . 6 6} \\
31.42\end{array}$ & $\begin{array}{l}\mathbf{8 0 0 . 5 8} \\
690.49\end{array}$ & $\begin{array}{l}\mathbf{8 5 4 . 7 7} \\
528.34\end{array}$ & $\begin{array}{c}\mathbf{2 8 2 5 . 3} \\
28.02\end{array}$ & $\begin{array}{r}\mathbf{2 8 3 2 . 5} \\
46.46\end{array}$ \\
\hline $\mathbf{P}$ & & 0.226 & 0.294 & 0.069 & 0.188 & 0.725 & 0.804 & $0.000^{*}$ & 0.000* \\
\hline
\end{tabular}

*Doses expressed as Mean $\pm \mathrm{SD}$.

Table 6: Comparison between the mean of the maximum doses received by the OARs

\begin{tabular}{|c|c|c|c|c|c|c|c|c|c|}
\hline Situation & & Rt Lens & Rt Eye & $\begin{array}{l}\text { Left } \\
\text { Lens }\end{array}$ & $\begin{array}{l}\text { Left } \\
\text { Eye }\end{array}$ & $\begin{array}{c}\text { Left } \\
\text { Optic } \\
\text { Nerve }\end{array}$ & $\begin{array}{c}\text { Rt } \\
\text { Optic } \\
\text { Nerve }\end{array}$ & $\begin{array}{c}\text { Optic } \\
\text { Chiasma }\end{array}$ & $\begin{array}{c}\text { Brain- } \\
\text { Stem }\end{array}$ \\
\hline $\begin{array}{c}\text { Non } \\
\text { Wedges }\end{array}$ & \multirow{3}{*}{$\begin{array}{l}\text { Max } \\
\pm \text { SD }\end{array}$} & $\begin{array}{c}\mathbf{3 1 2 . 1 1} \\
88.95\end{array}$ & $\begin{array}{l}\mathbf{2 3 8 5 . 8} \\
638.67\end{array}$ & $\begin{array}{c}290.19 \\
43.37\end{array}$ & $\begin{array}{l}\mathbf{2 2 9 5 . 4} \\
648.01\end{array}$ & $\begin{array}{c}\mathbf{3 0 1 5 . 7 9} \\
56.91\end{array}$ & $\begin{array}{c}\mathbf{3 0 3 6 . 5 4} \\
44.15\end{array}$ & $\begin{array}{c}\mathbf{3 0 9 2 . 1} \\
28.52\end{array}$ & $\begin{array}{c}3101.0 \\
21.54\end{array}$ \\
\hline $\begin{array}{l}\text { Similar } \\
\text { wedges }\end{array}$ & & $\begin{array}{c}\mathbf{3 2 6 . 7 5} \\
80.77\end{array}$ & $\begin{array}{c}\mathbf{2 3 6 5 . 0} \\
608.1\end{array}$ & $\begin{array}{c}299.62 \\
39.60\end{array}$ & $\begin{array}{l}\mathbf{2 2 7 0 . 0} \\
691.43\end{array}$ & $\begin{array}{c}\mathbf{2 9 7 3 . 5 9} \\
20.48\end{array}$ & $\begin{array}{c}\mathbf{2 9 7 1 . 2 7} \\
23.24\end{array}$ & $\begin{array}{c}\mathbf{2 9 8 5 . 0} \\
26.62\end{array}$ & $\begin{array}{c}\mathbf{2 9 6 7 . 8} \\
32.20\end{array}$ \\
\hline $\begin{array}{c}\text { Opposed } \\
\text { wedges }\end{array}$ & & \begin{tabular}{|c|}
$\mathbf{3 0 1 . 0 1}$ \\
72.10
\end{tabular} & $\begin{array}{l}2241 . \\
529.3\end{array}$ & $\begin{array}{l}\mathbf{2 6 9 . 8} \\
29.76\end{array}$ & $\begin{array}{c}2144.5 \\
592.0\end{array}$ & $\begin{array}{c}\mathbf{2 8 2 0 . 7 7} \\
55.98\end{array}$ & $\begin{array}{c}\mathbf{2 8 2 2 . 0 3} \\
42.02\end{array}$ & $\begin{array}{c}\mathbf{2 8 8 9 . 9} \\
32.67\end{array}$ & $\begin{array}{c}\mathbf{2 9 1 1 . 5} \\
26.23\end{array}$ \\
\hline $\mathbf{P}$ & & 0.422 & 0.464 & 0.053 & 0.490 & $0.000^{*}$ & $0.000^{*}$ & $0.000^{*}$ & $0.000^{*}$ \\
\hline
\end{tabular}

*Doses expressed as Mean \pm SD. 
Military Technical College

Kobry El-Kobbah,

Cairo, Egypt

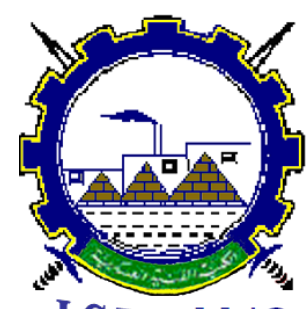

I.C.E.E.2018

\section{$9^{\text {th }}$ International Conference on}

Chemical \& Environmental

Engineering

3-5 April 2018

Table 7: Comparison between the mean of the mean doses received by the OARs

\begin{tabular}{|c|c|c|c|c|c|c|c|c|c|}
\hline Situation & & Rt Lens & $\begin{array}{c}\text { Rt } \\
\text { Eye }\end{array}$ & $\begin{array}{l}\text { Left } \\
\text { Lens }\end{array}$ & $\begin{array}{l}\text { Left } \\
\text { Eye }\end{array}$ & $\begin{array}{c}\text { Left } \\
\text { Optic } \\
\text { Nerve }\end{array}$ & $\begin{array}{c}\text { Rt } \\
\text { Optic } \\
\text { Nerve }\end{array}$ & $\begin{array}{c}\text { Optic } \\
\text { Chiasma }\end{array}$ & $\begin{array}{c}\text { Brain- } \\
\text { Stem }\end{array}$ \\
\hline $\begin{array}{c}\text { Non } \\
\text { Wedges }\end{array}$ & \multirow{3}{*}{$\begin{array}{c}\text { Mean } \\
\pm \text { SD }\end{array}$} & $\begin{array}{r}\mathbf{2 7 8 . 1 6} \\
58.98\end{array}$ & $\begin{array}{l}\mathbf{6 6 3 . 3} \\
323.2\end{array}$ & $\begin{array}{c}\mathbf{2 6 7 . 6 4} \\
50.61\end{array}$ & $\begin{array}{l}\mathbf{5 9 4 . 3 7} \\
267.24\end{array}$ & $\begin{array}{r}\mathbf{2 1 8 3 . 7 6} \\
521.19\end{array}$ & $\begin{array}{r}2243.29 \\
488.38\end{array}$ & $\begin{array}{c}\mathbf{3 0 6 9 . 6} \\
31.51\end{array}$ & $\begin{array}{r}\mathbf{3 0 6 2 . 8} \\
22.17\end{array}$ \\
\hline $\begin{array}{l}\text { Similar } \\
\text { wedges }\end{array}$ & & $\begin{array}{l}\mathbf{2 9 5 . 6 9} \\
52.07\end{array}$ & $\begin{array}{l}\mathbf{6 6 7 . 2} \\
311.5\end{array}$ & $\begin{array}{l}272.01 \\
28.05\end{array}$ & $\begin{array}{l}\mathbf{6 3 1 . 1 6} \\
280.35\end{array}$ & $\begin{array}{r}2169.755 \\
506.58\end{array}$ & $\begin{array}{l}2248.17 \\
438.39\end{array}$ & $\begin{array}{c}\mathbf{2 9 6 8 . 8} \\
31.39\end{array}$ & $\begin{array}{r}\mathbf{2 9 2 1 . 7} \\
32.12\end{array}$ \\
\hline $\begin{array}{c}\text { Opposed } \\
\text { wedges }\end{array}$ & & $\begin{array}{r}\mathbf{2 6 6 . 0 3} \\
50.40\end{array}$ & $\begin{array}{l}\mathbf{6 2 5 . 4} \\
294.8\end{array}$ & $\begin{array}{c}\mathbf{2 5 8 . 0 5} \\
38.99\end{array}$ & $\begin{array}{r}\mathbf{5 6 8 . 4 3} \\
251.07\end{array}$ & $\begin{array}{c}\mathbf{2 0 3 5 . 2 8 5} \\
472.47\end{array}$ & $\begin{array}{l}2166.09 \\
410.63\end{array}$ & $\begin{array}{r}\mathbf{2 8 5 8 . 2} \\
26.66\end{array}$ & $\begin{array}{r}2878.4 \\
32.08\end{array}$ \\
\hline $\mathbf{P}$ & & 0.208 & 0.722 & 0.296 & 0.606 & 0.557 & 0.611 & $0.000^{*}$ & $0.000 *$ \\
\hline
\end{tabular}

*Doses expressed as Mean \pm SD. 


\begin{tabular}{|c|c|}
\hline Proceeding of the $9^{\text {th }}$ ICEE Conference 3-5 April 2018 & NBC \\
Military Technical College \\
Kobry El-Kobbah, \\
Cairo, Egypt
\end{tabular}

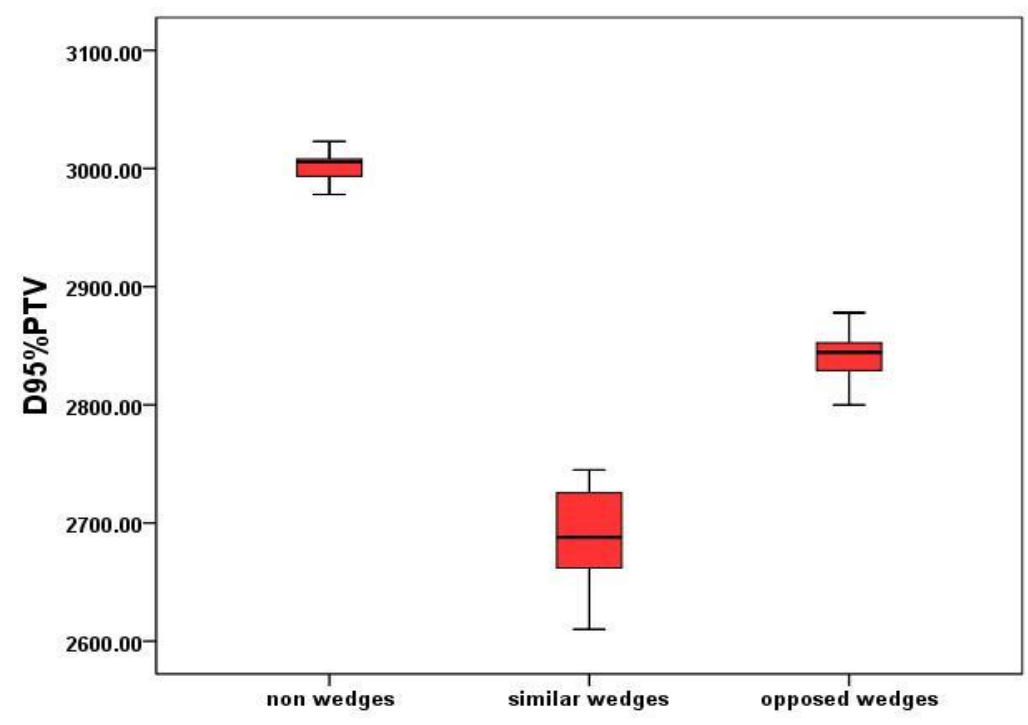

Fig. (1): D95 comparison between the different treatment planning.

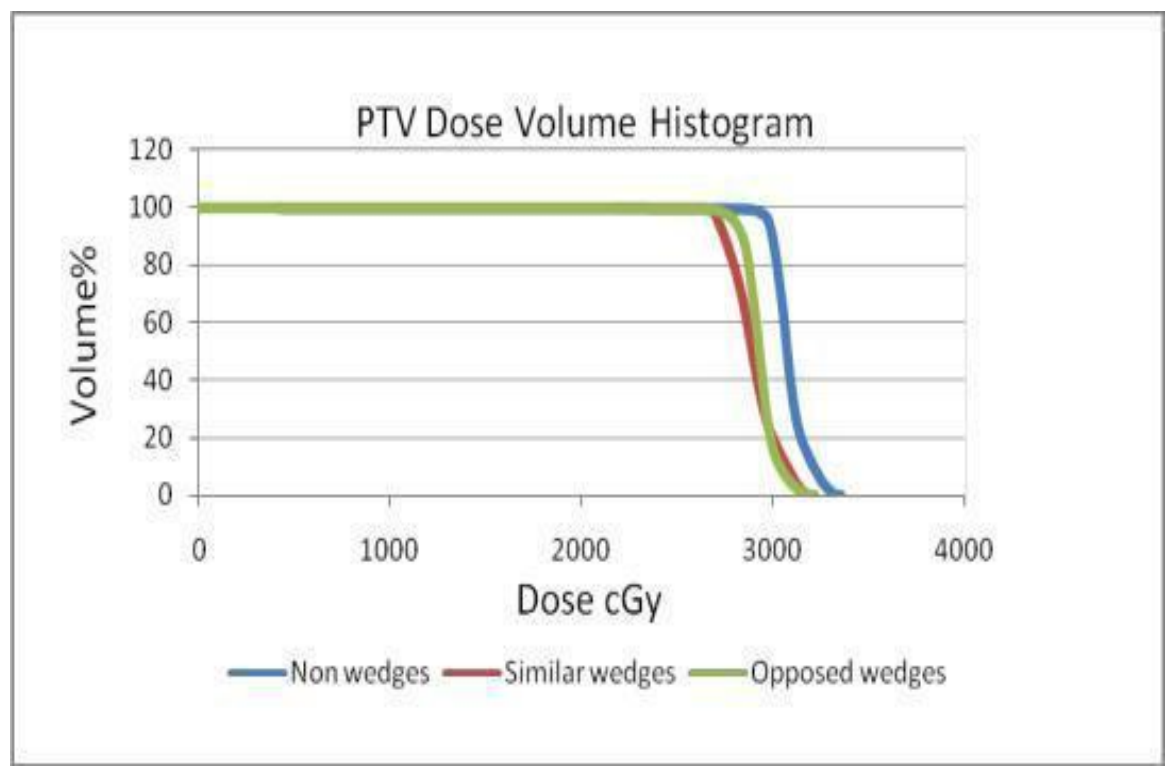

Fig. (2): Comparison of DVHs obtained for PTVwith the planningtechniques for one example patient. 


\begin{tabular}{|c|c|}
\hline Proceeding of the $9^{\text {th }}$ ICEE Conference 3-5 April 2018 & NBC \\
Military Technical College \\
Kobry El-Kobbah, \\
Cairo, Egypt
\end{tabular}

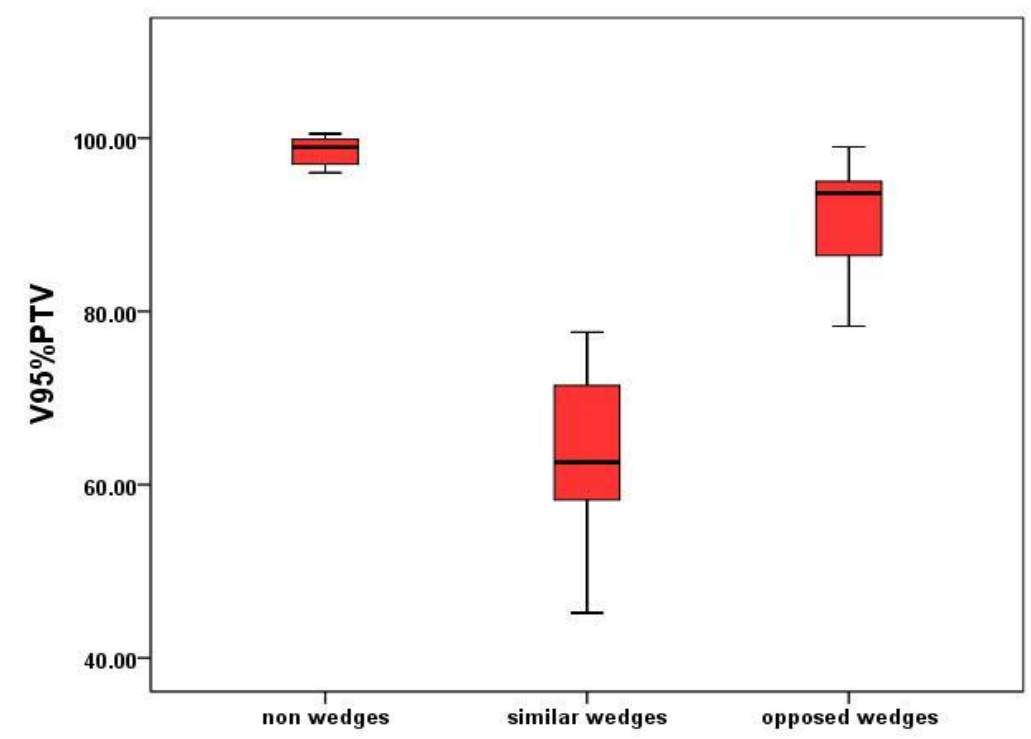

Fig. (3): V95 comparison between the different treatment planning.

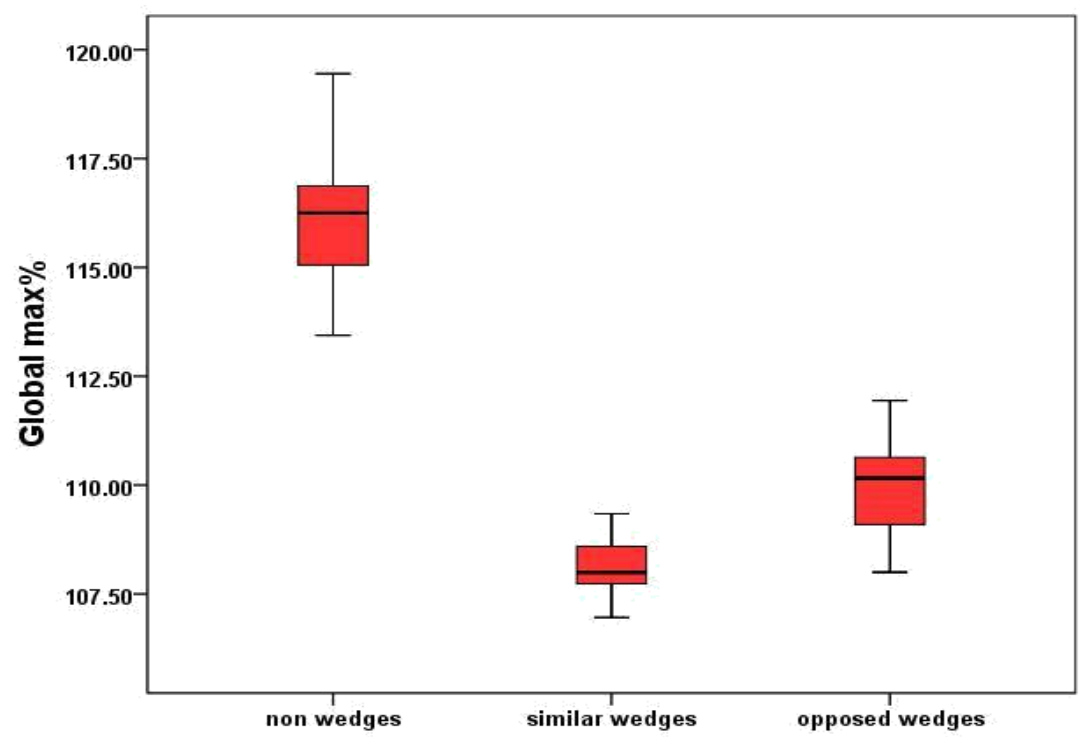

Fig. (4): Global Max illustration in the different treatment planning. 


\begin{tabular}{|c|c|}
\hline Proceeding of the $9^{\text {th }}$ ICEE Conference 3-5 April 2018 & NBC \\
Military Technical College \\
Kobry El-Kobbah, \\
Cairo, Egypt
\end{tabular}

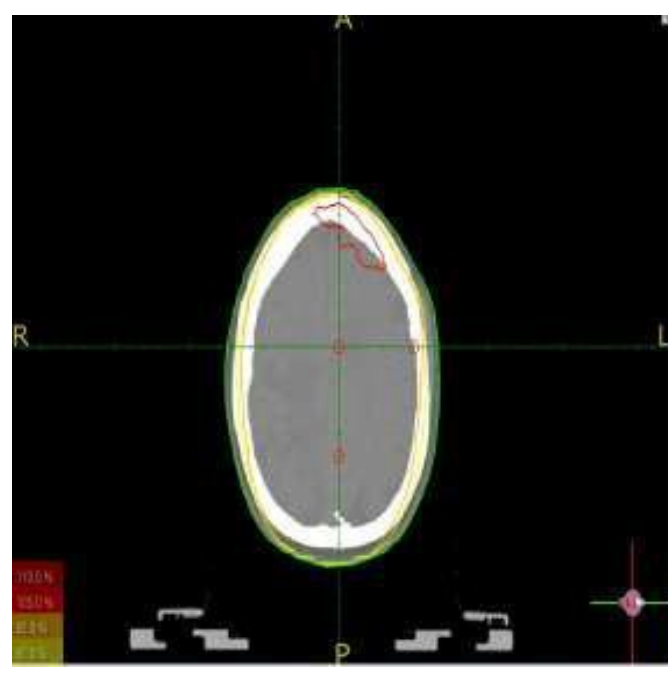

Fig. (5): opposed wedges.

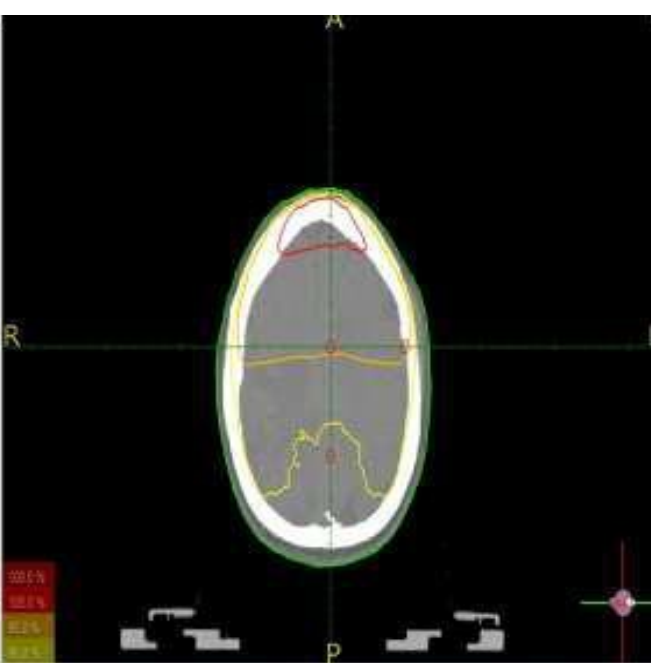

Fig.(6): similar wedges. 